\title{
NIGHT SHIFT WORK CHARACTERISTICS AND OCCUPATIONAL CO-EXPOSURES IN INDUSTRIAL PLANTS IN ŁÓDŹ, POLAND
}

\section{BEATA PEPŁOŃSKA ${ }^{1}$, WERONIKA BURDELAK ${ }^{1}$, AGNIESZKA BUKOWSKA ${ }^{1}$, JOLANTA KRYSICKA ${ }^{1}$, and KATARZYNA KONIECZKO ${ }^{2}$}

${ }^{1}$ Nofer Institute of Occupational Medicine, Łódź, Poland

Department of Environmental Epidemiology

${ }^{2}$ Nofer Institute of Occupational Medicine, Łódź, Poland

Department of Chemical Safety

\begin{abstract}
Objectives: Night shift work involving circadian rhythm disruption has been classified by IARC as a probably carcinogenic to humans (Group 2A). Little is known about co-exposures of the night shift work in occupational settings. The aim of our study was to characterize night shift work systems and industrial exposures occurring in the manufacturing plants in Lódź, Poland, where night shift work system operates, with particular focus on potential carcinogens. Material and Methods: Data on the night shift work systems and hazardous agents were collected through survey performed in 44 enterprises. The identified hazardous agents were checked using the IARC carcinogen list, and the harmonized EU classification of chemical substances. We also examined databases of the Central Register of Data on exposure to substances, preparations, agents and technological processes showing carcinogenic or mutagenic properties in Poland. Results: The most common system of work among studied enterprises employed 3 (8-hour) shifts within a 5-day cycle. We identified as many as 153 hazards occurring in the environment of the plants, with noise, carbon monoxide and formaldehyde recorded as the most common ones. Out of these hazards, 11 agents have been classified by IARC to group 1 - carcinogenic to humans, whereas 10 agents have been classified as carcinogens by the regulation of European Classification of carcinogens. Analysis of the data from the Central Register revealed that 6 plants reported presence of carcinogens in the environment of work. Conclusions: In our study we observed that in none of the workplaces the night shift work was a single exposure. Further epidemiological studies focusing on investigation of health effects of the night shift work should identify occupational co-exposures and examine them as potential confounders.
\end{abstract}

Key words:

Industry, Night shift work, Occupational exposure, Carcinogenic agents

\section{INTRODUCTION}

Night shift work, as a potentially carcinogenic occupational factor, has been of interest to epidemiologists since 1987, when the hypothesis on the link between exposure to light at night and cancer was formulated for the first time [1]. The majority of epidemiological studies that had been published before IARC experts issued their opinion in 2007 on shift work that involves circadian rhythm disruption as a probable carcinogen in humans, had been carried out mostly in nurses and flight attendants. It had been also concluded that shift work that includes night work is the most disruptive to the circadian system. The need for

This project is supported by a grant "The risk of selected cancers in the night shift workers" from the National Science Centre, Grant No: PB5169/B/P01/2010/38. Received: January 1, 2013. Accepted: July 23, 2013.

Corresponding author: B. Pepłońska, Department of Environmental Epidemiology, Nofer Institute of Occupational Medicine, św. Teresy 8, 91-348 Łódź, Poland (e-mail: beatap@imp.lodz.pl). 
further studies was expressed as follows: "more studies are needed to examine this potential risk in other professions and for other cancers" (Dr Cogliano, Head of the IARC Monographs Programme) [2,3].

Over the past 5 years, eight additional epidemiological studies have been reported, including: three investigations in nurses: a Norwegian nested case-control study on breast cancer [4], a Danish nested case-control study on breast cancer [5], an ovarian cancer in Nurses Health Study [6], as well as a breast cancer case-control study in Germany [7], and France - breast cancer case-control CECILE study [8], industrial males cohort in Japan - a study on prostate cancer [9], and females in China - a study on breast cancer [10]. Moreover, one registry-based linkage study was conducted in Scandinavian countries [11]. In 4 of these investigations, a statistically significant increase in cancer risk was observed, but again, the majority of these investigations have been focused on breast cancer and on nurses populations.

In most cases, exposure experienced in the occupational settings is complex, and rarely only one occupational hazard factor is present. Even in such specific occupational settings as hospitals, exposure to several agents might be recorded. Apart from night shift work, exposure to ionizing radiation, cytostatics, organic solvents, anesthetic gases, sterilizants, viruses and other biological agents may affect hospital staff. Ionizing radiation is an established breast cancer risk factor, while several others listed above have been linked to breast cancer, e.g. cytostatics or organic solvents. In only two epidemiological analyses carried out so far, which investigated the association between night shift work and breast cancer risk in nurses, other exposures have been examined as potential confounders, i.e. exposure to electromagnetic fields and ionizing radiation $[4,5]$. In none of the other investigations examining the links between night shift work and cancer risk, other occupational exposures have been addressed. In fact, little is known on industrial exposure occurring in the manufacturing plants where night shift work system operates.
Following IARC recommendation on continuing studies on the risk of cancer in populations other than flight attendants or nurses, an industrial cohort study on night shift workers is being set up in Łódź, Poland. In order to characterize working conditions of night shift workers, we carried out an analysis of 44 industrial plants in the region. We collected detailed information on the system of work in each of these occupational settings (including the number of shifts, starting hours, rotating pace and direction) and other exposures that were identified in the plants' environment. IARC monographs and the list of European Classification of Carcinogens were explored in order to identify which of these agents have been evaluated in respect to their potential carcinogenicity and categorized as carcinogenic or probably/possibly carcinogenic to humans.

\section{METHODS}

The list of manufactures operating on the shift system, including night shifts in Łódź was obtained from the District Sanitary-Epidemiological Station (SANEPID) in Łódź. SANEPID is responsible for monitoring and control of all workplaces in Łódź municipal region, and it collects information about employers, according to regulations in Poland (Labour Code). The list included as many as 75 enterprises. Since economical situation of Łódź is dynamic, in particular for small scale enterprises, and because larger companies have usually better quality databases for the cohort studies, only enterprises employing at least 100 workers were selected. Exposure data were collected for the same enterprises, leaving 44 items for the analysis. To identify economic activities of the identified enterprises, the database of the Central Statistical Office in Poland - REGON registry was explored. This database contains a continuously updated set of information on the subjects of national economy, with the activities of the enterprises encoded according to the Polish Classification of Activities (Polska Klasyfikacja Działalności - PKD) 
ver. 2007, which has been developed on the basis of the European Classification of Activities [12].

Information on the number of employed workers, by sex and by job type (white/blue-collar), description of the shift system operating in the plant (number of shifts, hours of starting and ending the shift, number of consecutive shifts, direction of rotation, and rate of rotation) was collected via a questionnaire filled in by the personnel of inspectors of safety and hygiene and by the human resources departments of the examined plants. An open question seek information about all occupational hazards present within the plant environment. SANEPID's inspectors collected questionnaires and checked their completeness, as well as verified the data using SANEPID records. The next step of verification of data about potential carcinogens involved checking SANEPID controlling reports in order to assess whether particular agent was present in the plant, how many workers were exposed, at which jobs and whether in the case of any measurements during the years 2006-2011 the threshold limits were exceeded.

In order to identify whether hazards reported by the manufactures have been classified as carcinogens we examined two classifications of carcinogens 1) European classification of chemical substances according to the EC Regulation [13] (called also CLP) and 2) classification of the International Agency for Research on Cancer [14]. We identified the hazards classified to the following groups by CLP - Classification, Labelling, Packaging Category 1 - "substances which are known or presumed to be carcinogenic to humans":

- 1A - "carcinogenic potential for humans, evidence based on research carried out in humans".

- 1B - "carcinogenic potential for humans, evidence based on studies in animals".

And by IARC classification:

- Group 1 - "The agent is carcinogenic to humans".

- Group 2A - "The agent is probably carcinogenic to humans".
- Group 2B - "The agent is possibly carcinogenic to humans".

Finally, the databases of the Central Register of Data on exposure to substances, preparations, agents and technological processes showing carcinogenic or mutagenic properties in Poland were examined to identify manufactures that reported the occurrence of any occupational carcinogenic hazards. The databases were examined for the data since 2005 .

\section{RESULTS}

Table 1 presents the total number of employees and the proportions of night shift workers among all the employees by gender in the enterprises grouped by PKD. 44 enterprises included into the analysis represented 16 activities according to PKD, out of which the most common were: PKD 22 - Manufacture of rubber and plastic products (9 plants), PKD 13 - Manufacture of textiles (7 plants), and PKD 49 - Land transport and transport via pipelines ( 6 plants). Total population of workers of these enterprises amounted to 18298 persons (6559 women and 11739 men), with the majority of blue-collar workers $(83.3 \%)$. As many as $66 \%$ of the blue-collar workers worked on night shifts $(63 \%$ of women and $68 \%$ of men holding blue-collar positions). The proportion of night shift workers varied by PKD category with the highest percent of women working on night shifts in PKD 31 - manufacture of furniture, and males working on night shifts in manufacture of food. The lowest percentage of night shift workers was reported in the wholesale trade (around 19\% both among males and females).

\section{Characteristics of the night shift work system in the $\mathbf{4} 4$ selected enterprises in Lódź}

Table 2 presents the numbers and percentages of enterprises and blue-collar workers employed within the specific shift system. The most prevalent shift work system 
Table 1. Total number of workers and night shift workers in 44 enterprises by PKD

\begin{tabular}{|c|c|c|c|c|c|c|c|c|}
\hline \multirow[b]{2}{*}{ PKD Category } & \multirow[b]{2}{*}{$\begin{array}{l}\text { Plants } \\
\text { (n) }\end{array}$} & \multirow[b]{2}{*}{$\begin{array}{l}\text { Employees } \\
\text { (total) } \\
\text { (n) }\end{array}$} & \multicolumn{3}{|c|}{ Females } & \multicolumn{3}{|c|}{ Males } \\
\hline & & & $\begin{array}{l}\text { employees } \\
\text { (total) } \\
\text { (n) }\end{array}$ & $\begin{array}{l}\text { night shift } \\
\text { workers } \\
\text { (n) }\end{array}$ & $\begin{array}{l}\text { night shift } \\
\text { workers } \\
(\%)\end{array}$ & $\begin{array}{l}\text { employees } \\
\text { (total) } \\
\text { (n) }\end{array}$ & $\begin{array}{l}\text { night shift } \\
\text { workers } \\
\text { (n) }\end{array}$ & $\begin{array}{l}\text { night shift } \\
\text { workers } \\
(\%)\end{array}$ \\
\hline 10 - Manufacture of food & 1 & 391 & 246 & 198 & 80.5 & 145 & 134 & 92.4 \\
\hline 11 - Manufacture of beverages & 1 & 160 & 22 & 12 & 54.5 & 138 & 115 & 83.3 \\
\hline 13 - Manufacture of textiles & 7 & 1417 & 766 & 520 & 67.9 & 651 & 401 & 61.6 \\
\hline 14 - Manufacture of wearing apparel & 3 & 588 & 444 & 21 & 4.7 & 144 & 43 & 29.9 \\
\hline $\begin{array}{l}17 \text { - Manufacture of paper and paper } \\
\text { products }\end{array}$ & 1 & 233 & 40 & 14 & 35.0 & 193 & 156 & 80.8 \\
\hline $\begin{array}{l}18 \text { - Printing and reproduction of } \\
\text { recorded media }\end{array}$ & 2 & 619 & 165 & 63 & 38.2 & 454 & 323 & 71.1 \\
\hline $\begin{array}{l}22 \text { - Manufacture of rubber and } \\
\text { plastic products }\end{array}$ & 9 & 3019 & 1394 & 819 & 58.8 & 1625 & 1059 & 65.2 \\
\hline $\begin{array}{l}25 \text { - Manufacture of fabricated metal } \\
\text { products }\end{array}$ & 2 & 1397 & 440 & 328 & 74.5 & 957 & 721 & 75.4 \\
\hline $\begin{array}{l}27 \text { - Manufacture of electrical } \\
\text { equipment }\end{array}$ & 4 & 4383 & 1282 & 247 & 19.3 & 3101 & 1278 & 41.2 \\
\hline 31 - Manufacture of furniture & 1 & 580 & 212 & 195 & 92.0 & 368 & 332 & 90.2 \\
\hline $\begin{array}{l}35 \text { - Electricity, gas, steam and air } \\
\text { conditioning supply }\end{array}$ & 3 & 1237 & 173 & 17 & 9.8 & 1064 & 754 & 70.9 \\
\hline 37 - Sewerage & 1 & 239 & 42 & 0 & 0.0 & 197 & 98 & 49.7 \\
\hline $\begin{array}{l}46 \text { - Wholesale trade, except for } \\
\text { motor vehicles }\end{array}$ & 1 & 598 & 299 & 55 & 18.4 & 299 & 57 & 19.1 \\
\hline $\begin{array}{l}49 \text { - Land transport and transport via } \\
\text { pipelines }\end{array}$ & 6 & 2331 & 312 & 141 & 65.2 & 2019 & 1087 & 53.3 \\
\hline 77 - Rental and leasing activities & 1 & 121 & 86 & 75 & 87.2 & 35 & 31 & 88.6 \\
\hline $\begin{array}{l}82 \text { - Office administrative, office } \\
\text { support and other business support } \\
\text { activities }\end{array}$ & 1 & 985 & 985 & 539 & 85.2 & 352 & 299 & 84.9 \\
\hline Total & 44 & 18298 & 6559 & 3244 & 49.5 & 11739 & 6888 & 58.7 \\
\hline
\end{tabular}

PKD - Polish Classification of Activities (Polska Klasyfikacja Działalności).

included three shifts (31 plants $-70.4 \%$ ), with a morning, afternoon, and night shift. The typical hours of work in the 3-shift system are: morning shift: from 5:15-6:00 a.m. to 1:30-2:00 p.m.; afternoon shift: from 1:15-2:00 p.m. to 9:30-10:00 p.m., and night shift: from 9:15-10:00 p.m. to 5:30-6:00 a.m. As many as $61.2 \%$ of the examined night shift workers were employed within a 3-shift system. A system other than 3- or 2-shift system operated in $27 \%$ of the examined enterprises. The category "other systems" comprised mixed: 2-, 3-, 4-shift systems.

The system with 5 consecutive shifts, operating in 21 enterprises $(\sim 52 \%$ of the blue-collar night shift workers) appeared to be the most typical. A fast rotating system (defined as one including 3 or fewer consecutive shifts) was recorded in 11 enterprises $(\sim 26 \%$ of the blue-collar workers) (Table 3). No slow rotating system, 
Table 2. Characteristics of the plants according to the system of work

\begin{tabular}{|c|c|c|c|c|}
\hline \multirow{2}{*}{ System of work } & \multicolumn{2}{|c|}{ Enterprises } & \multicolumn{2}{|c|}{ Night shift workers } \\
\hline & $\mathrm{n}$ & $\%$ & $\mathrm{n}$ & $\%$ \\
\hline 3-shift & 31 & 70.4 & 6198 & 61.2 \\
\hline \multicolumn{5}{|l|}{ Typical hour of beginning of the shift } \\
\hline $\begin{array}{l}\text { category } 1 \text { (morning shift: 5:15-6:00 a.m.; afternoon } \\
\text { shift: 1:15-2:00 p.m.; night shift: 9:15-10.00 p.m.) }\end{array}$ & 14 & 45.2 & 2557 & 41.3 \\
\hline $\begin{array}{l}\text { category } 2 \text { (morning shift: 6:00 a.m.; afternoon: 2:00 p.m.; } \\
\text { night shift: 10:00 p.m.) }\end{array}$ & 17 & 54.8 & 3641 & 58.7 \\
\hline 2-shift & 1 & 2.3 & 69 & 0.7 \\
\hline Other systems & 12 & 27.3 & 3865 & 38.1 \\
\hline Total & 44 & 100.0 & 10132 & 100.0 \\
\hline
\end{tabular}

Table 3. The enterprises (night shift workers) by shift cycles

\begin{tabular}{lcrrr}
\hline \multirow{2}{*}{$\begin{array}{c}\text { Consecutive } \\
\text { shifts }\end{array}$} & \multicolumn{2}{c}{ Enterprises } & \multicolumn{2}{c}{ Night shift workers } \\
\cline { 2 - 5 } & $\mathrm{n}$ & \multicolumn{1}{c}{$\%$} & \multicolumn{1}{c}{$\mathrm{n}$} & \multicolumn{1}{c}{$\%$} \\
\hline 7 & 2 & 4.5 & 324 & 3.2 \\
6 & 4 & 9.1 & 526 & 5.2 \\
5 & 21 & 47.8 & 5250 & 51.8 \\
4 & 6 & 13.6 & 1411 & 13.9 \\
3 & 1 & 2.3 & 152 & 1.5 \\
2 & 2 & 4.5 & 52 & 0.5 \\
1 & 8 & 18.2 & 2417 & 23.9 \\
Total & 44 & 100.0 & 10132 & 100.0 \\
\hline
\end{tabular}

i.e. every 15-30 days, functioned in any of the studied enterprises.

Counter-clockwise rotation, i.e. afternoon/morning/night rotation, operated in majority of the enterprises (23 enterprises $-61 \%$ of the employees working on night shifts), while clockwise rotation, i.e. morning/afternoon/night rotation was noted in 15 enterprises (34\%).

\section{Occupational exposure in the 44 enterprises with the night shift system in Lódź}

The full list of all reported occupational hazards encompassed 153 items, out of which chemical hazards (105) comprised majority. 44 physical hazards (including various dusts), 2 psychophysical ones and 2 biological ones were also listed. The most frequent exposure, i.e. the one reported by $93 \%$ of the enterprises, was noise, then carbon monoxide (56.8\%), formaldehyde (43.2\%) nitrogen oxide and nitrogen dioxide (both by $31.8 \%$ enterprises). In 4 enterprises that are classified to PKD 27 - Manufacture of electrical equipment, as many as 71 hazardous agents were reported.

\section{Carcinogenic hazards, according to IARC classification, reported in the 44 enterprises in Lódź}

Examination of the list of hazardous agents against the list of carcinogens formulated by IARC, let us identify 20 agents that have been classified by IARC into 3 groups $(1,2 \mathrm{~A}$, and $2 \mathrm{~B})$ :

- IARC Group 1 - formaldehyde, mineral oils, silica dusts (including dust containing free crystalline silica), nickel compounds, benzene, cadmium and cadmium compounds, wood dust, benzo[a]pyrene, chromium(VI) compounds, Diesel engine exhaust, vinyl chloride.

- IARC Group 2A - tetrachloroethylene.

- IARC Group 2B - styrene, ethylbenzene, nickel, lead, cumene, toluene diisocyanate, gasoline, heavy fuel oil.

Out of the reported carcinogenic exposures, formaldehyde was the most common one, reported by 19 enterprises, classified to eight categories of PKD. Mineral oils 
were reported in 8 enterprises (5 categories of PKD) and silica dusts were reported also in 8 enterprises (6 categories of PKD) (Table 4). The potential presence of hazards classified to Group 1 by IARC was reported by 26 enterprises, classified to 12 categories of PKD.

The greatest number of agents potentially carcinogenic from Group 1, 2A and 2B by IARC ( 9 agents) was reported within the category of PKD No 27 - Manufacture of electrical equipment (chromium(VI) compounds, ethylbenzene, formaldehyde, cadmium and cadmium compounds, cumene, nickel, mineral oils, silica dusts and styrene), and the category of PKD No 49 - Land transport and transport via pipelines (benzene, benzo[a]pyrene, ethylbenzene, formaldehyde, mineral oils, lead, silica dusts, styrene, Diesel engine exhaust).

Table 4. Selected exposures present in the 44 plants (classified by IARC to Group 1, 2A, 2B) - survey data

\begin{tabular}{|c|c|c|c|c|c|}
\hline \multirow{2}{*}{ Name of the agent } & \multirow{2}{*}{$\begin{array}{c}\text { IARC } \\
\text { classification }\end{array}$} & \multirow{2}{*}{$\begin{array}{l}\text { European } \\
\text { classification } \\
\text { (CLP) }\end{array}$} & \multicolumn{2}{|c|}{ Plants } & \multirow{2}{*}{ Categories of PKD } \\
\hline & & & $\mathrm{n}$ & $\%$ & \\
\hline Formaldehyde & 1 & & 19 & 43.2 & $\begin{array}{l}18 \text { - Printing and reproduction of recorded media; } 22 \text { - Manu- } \\
\text { facture of rubber and plastic products; } 25 \text { - Manufacture of } \\
\text { fabricated metal products; } 27 \text { - Manufacture of electrical } \\
\text { equipment; } 35 \text { - Electricity, gas, steam and air conditioning } \\
\text { supply; } 37 \text { - Sewerage; } 49 \text { - Land transport and transport } \\
\text { via pipelines; } 77 \text { - Rental and leasing activities }\end{array}$ \\
\hline $\begin{array}{l}\text { Mineral oils (if they } \\
\text { contain PAH) }\end{array}$ & 1 & $1 \mathrm{~B}$ & 8 & 18.2 & $\begin{array}{l}25 \text { - Manufacture of fabricated metal products; } 27 \text { - Manu- } \\
\text { facture of electrical equipment; } 35 \text { - Electricity, gas, steam and } \\
\text { air conditioning supply; } 37 \text { - Sewerage; } 49 \text { - Land transport and } \\
\text { transport via pipelines }\end{array}$ \\
\hline Silica dusts & 1 & & 8 & 18.2 & $\begin{array}{l}13 \text { - Manufacture of textiles; } 14 \text { - Manufacture of wearing } \\
\text { apparel; } 25 \text { - Manufacture of fabricated metal products; } 27 \text { - } \\
\text { Manufacture of electrical equipment; } 37 \text { - Sewerage; } 49 \text { - Land } \\
\text { transport and transport via pipelines }\end{array}$ \\
\hline Styrene & $2 \mathrm{~B}$ & & 6 & 13.6 & $\begin{array}{l}22 \text { - Manufacture of rubber and plastic products; } 25 \text { - Manu- } \\
\text { facture of fabricated metal products; } 27 \text { - Manufacture } \\
\text { of electrical equipment; } 49 \text { - Land transport and transport } \\
\text { via pipelines }\end{array}$ \\
\hline Ethylbenzene & $2 \mathrm{~B}$ & & 5 & 11.4 & $\begin{array}{l}22 \text { - Manufacture of rubber and plastic products; } 27 \text { - Manu- } \\
\text { facture of electrical equipment; } 49 \text { - Land transport and } \\
\text { transport via pipelines }\end{array}$ \\
\hline Nickel & $2 \mathrm{~B}$ & & 3 & 6.8 & $\begin{array}{l}11 \text { - Manufacture of beverages; } 25 \text { - Manufacture of fabricated } \\
\text { metal products; } 27 \text { - Manufacture of electrical equipment }\end{array}$ \\
\hline Lead & $2 \mathrm{~B}$ & & 3 & 6.8 & $\begin{array}{l}25 \text { - Manufacture of fabricated metal products; } 49 \text { - Land } \\
\text { transport and transport via pipelines }\end{array}$ \\
\hline $\begin{array}{l}\text { Chromium }(\mathrm{VI}) \\
\text { compounds }\end{array}$ & 1 & 1B & 2 & 4.5 & $\begin{array}{l}25 \text { - Manufacture of fabricated metal products; } 27 \text { - Manu- } \\
\text { facture of electrical equipment }\end{array}$ \\
\hline Vinyl chloride & 1 & $1 \mathrm{~A}$ & 1 & 2.2 & 10 - Manufacture of food products \\
\hline Nickel compounds & 1 & $1 A^{*}$ & 1 & 2.2 & 11 - Manufacture of beverages \\
\hline Benzene & 1 & $1 \mathrm{~A}$ & 1 & 2.2 & 49 - Land transport and transport via pipelines \\
\hline
\end{tabular}


Table 4. Selected exposures present in the 44 plants (classified by IARC to Group 1, 2A, 2B) - survey data - cont.

\begin{tabular}{|c|c|c|c|c|c|}
\hline \multirow{2}{*}{ Name of the agent } & \multirow{2}{*}{$\begin{array}{c}\text { IARC } \\
\text { classification }\end{array}$} & \multirow{2}{*}{$\begin{array}{c}\text { European } \\
\text { classification } \\
(\mathrm{CLP})\end{array}$} & \multicolumn{2}{|c|}{ Plants } & \multirow{2}{*}{ Categories of PKD } \\
\hline & & & $\mathrm{n}$ & $\%$ & \\
\hline Tetrachloroethylene & $2 \mathrm{~A}$ & & 1 & 2.2 & 22 - Manufacture of rubber and plastic products \\
\hline $\begin{array}{l}\text { Cadmium and } \\
\text { cadmium } \\
\text { compounds }\end{array}$ & 1 & $1 \mathrm{~B}^{*}$ & 1 & 2.2 & 27 - Manufacture of electrical equipment \\
\hline Cumene & $2 \mathrm{~B}$ & & 1 & 2.2 & 27 - Manufacture of electrical equipment \\
\hline Wood dust & 1 & carcinogen** & 1 & 2.2 & 35 - Electricity, gas, steam and air conditioning supply \\
\hline Toluene diisocyanate & $2 \mathrm{~B}$ & & 1 & 2.2 & 22 - Manufacture of rubber and plastic products \\
\hline Benzo $[a]$ pyrene & 1 & 1B & 1 & 2.2 & 49 - Land transport and transport via pipelines \\
\hline Gasoline & $2 \mathrm{~B}$ & $\begin{array}{c}1 \mathrm{~B} \\
(\mathrm{NOTE} P)^{* * *}\end{array}$ & 1 & 2.2 & 25 - Manufacture of fabricated metal products \\
\hline Heavy fuel oil & $2 \mathrm{~B}$ & $1 \mathrm{~B}$ & 1 & 2.2 & 35 - Electricity, gas, steam and air conditioning supply \\
\hline $\begin{array}{l}\text { Diesel engine } \\
\text { exhaust }\end{array}$ & 1 & $1 \mathrm{~B}^{* * * *}$ & 1 & 2.2 & 49 - Land transport and transport via pipelines \\
\hline
\end{tabular}

IARC - International Agency for Research on Cancer; PKD - Polish Classification of Activities (Polska Klasyfikacja Działalności).

* Selected substances according to CLP.

** Work involving exposure to hardwood dusts is treated as carcinogenic according to Annex I, Dir. 2004/37/EC [15].

*** Note $\mathrm{P}$ - this note applies only to certain complex oil-derived substances - the classification as a carcinogen or mutagen need not apply if it can be shown that the substance contains less than $0.1 \%$ w/w benzene (EINECS No 200-753-7).

**** Selected PAHs contained in Diesel engine exhaust according to CLP.

\section{Carcinogenic hazards according to the European} classification of carcinogens reported in the 44

\section{enterprises in Lódź}

Out of the exposures potentially occurring in the environment of the enterprises, as many as 10 were classified to category $1 \mathrm{~A}$ ( 3 agents) or $1 \mathrm{~B}$ (7 agents):

- 1A - benzene, vinyl chloride, nickel compounds;

- 1B - benzo[a]pyrene, chromium(VI) compounds, cadmium and cadmium compounds, gasoline, heavy fuel oil, mineral oils (if they contain PAH), Diesel engine exhaust (due to PAH content).

Benzene was reported only by one enterprise in PKD 49 - Land transport and transport via pipelines. Out of the agents classified to group $1 \mathrm{~B}$, mineral oils were the most frequently reported ones - by 8 enterprises (Table 4).

\section{Carcinogens present in the enterprises} according to the Central Register of Data on exposure to substances, preparations, agents and technological processes showing carcinogenic or mutagenic properties in Poland

Examination of the data of the Central Registry in Poland for the period 2005-2010 revealed that 6 out of 44 manufactures reported presence of carcinogens in their occupational environment (Table 5). As many as 11 various carcinogenic agents were reported, and only two of them, i.e. chromium trioxide in the manufacture producing electrical equipment (PKD-27), and heavy fuel oil in the plant classified to PKD 35 - producing electricity, gas, steam and air conditioning supply, were reported every year throughout the period 2005-2010, while others were reported only during selected years. The average 
Table 5. Carcinogens present in the examined enterprises and identified in the Central Register of data on exposure to substances, preparations, agents and technological processes showing carcinogenic or mutagenic properties, in the period 2005-2010

\begin{tabular}{|c|c|c|c|c|c|}
\hline \multirow[t]{2}{*}{ Category of PKD } & \multirow{2}{*}{$\begin{array}{l}\text { Plants } \\
(\mathrm{n})\end{array}$} & \multirow[t]{2}{*}{ Agent (period of exposure) } & \multicolumn{3}{|c|}{$\begin{array}{c}\text { Exposed employees (maximum) } \\
(\mathrm{n})\end{array}$} \\
\hline & & & total & women & men \\
\hline $\begin{array}{l}22 \text { - Manufacture of } \\
\text { rubber and plastic } \\
\text { products }\end{array}$ & 1 & trichloroethylene (2005-2007) & 34 & 15 & 19 \\
\hline \multirow{6}{*}{$\begin{array}{l}27 \text { - Manufacture of } \\
\text { electrical equipment }\end{array}$} & \multirow[t]{6}{*}{1} & chromium trioxide (2005-2010) & 5 & 0 & 5 \\
\hline & & cobalt sulfate (2006-2010) & 5 & 0 & 5 \\
\hline & & potassium chromate (2007-2010) & 3 & 3 & 0 \\
\hline & & potassium dichromate (2008) & 1 & 1 & 0 \\
\hline & & $\begin{array}{l}\text { chromium compounds, with the exception of barium } \\
\text { chromate and others from the list (2007) }\end{array}$ & 1 & 1 & 0 \\
\hline & & arsenic (III) oxide (2007) & 2 & 2 & 0 \\
\hline \multirow{2}{*}{$\begin{array}{l}35 \text { - Electricity, gas, } \\
\text { steam and air } \\
\text { conditioning supply }\end{array}$} & \multirow[t]{2}{*}{3} & fuel oil No 6; heavy fuel oil (2005-2010) & 49 & 0 & 49 \\
\hline & & $\begin{array}{l}\text { distillates heavy paraffinic, hydrotreated (petroleum) } \\
\text { base oil - unspecified }(2006,2008-2010)\end{array}$ & 13 & 0 & 13 \\
\hline \multirow[t]{5}{*}{37 - Sewerage } & \multirow[t]{5}{*}{1} & potassium dichromate $(2008,2010)$ & 10 & 9 & 1 \\
\hline & & arsenic (III) oxide $(2008,2010)$ & 3 & 3 & 0 \\
\hline & & 1,2-dichloroethane $(2008,2010)$ & 2 & 2 & 0 \\
\hline & & trichloroethylene $(2008,2010)$ & 2 & 2 & 0 \\
\hline & & hexachlorobenzene $(2008,2010)$ & 2 & 2 & 0 \\
\hline
\end{tabular}

Abbreviation as in Table 1.

number of employees exposed to specific agents was relatively small (and included predominantly men), with the maximum number of the exposed subjects up to 49 (to heavy fuel oil) in PKD 35 - Electricity, gas, steam and air conditioning supply.

Table 6 summarizes data from epidemiological or animal studies about chemicals identified in our dataset that has been linked to breast, prostate or colon cancer - some epidemiological studies concerning people working at night indicated an increased risk of development of the cancers of these sites. According to IARC evaluations none of these chemicals have been strongly associated with cancers of concern. As shown, exposure to styrene, suggested to be linked to breast cancer, was the most prevalent - 178 exposed workers according to SANEPID.

\section{DISCUSSION}

Night shift work is performed by about $15-20 \%$ of the working population in Europe and the USA. This system of work is the most prevalent in the health sector (35.5\%), hotels and restaurants (29.9\%), industrial manufacturing and mining (25.8\%), transport and communication (24.1\%), as well as plant and machine operating and assembling (34.5\%) [3].

According to the official Polish statistics (2011) night shift work is performed by about $7.8 \%$ of the general population of Polish workers, which is one of the lowest among European countries. Of all night shift employees in Poland most of them are employed in manufacturing (35.9\%), human health and social work activities (16.6\%), and 
Table 6. Selected chemicals present in the environment of the examined enterprises, number of potentially exposed workers (according to SANEPID records) and cancer sites linked to the exposure

\begin{tabular}{|c|c|c|c|}
\hline \multirow{2}{*}{$\begin{array}{l}\text { Chemical (IARC category) - } \\
\text { exposed persons }(\mathrm{n})\end{array}$} & \multicolumn{2}{|c|}{ Target organs in humans } & \multirow{2}{*}{$\begin{array}{l}\text { Target organs in animals - sufficient } \\
\text { or limited evidence }\end{array}$} \\
\hline & sufficient evidence & limited evidence & \\
\hline Styrene $(2 B)-178$ & & $\begin{array}{l}\text { leukemia and/or } \\
\text { lymphoma }\end{array}$ & lung, mammary gland \\
\hline Benzene (1) -4 & $\begin{array}{l}\text { leukemia and/or } \\
\text { lymphoma }\end{array}$ & & $\begin{array}{l}\text { harderian gland, hematopoietic system, lung, } \\
\text { mammary gland, skin, oral cavity, ovary, } \\
\text { preputial gland, Zymbal gland }\end{array}$ \\
\hline $\begin{array}{l}\text { Cadmium and cadmium } \\
\text { compounds (1) }-13\end{array}$ & lung & prostate, kidney & $\begin{array}{l}\text { lung, testis (cadmium chloride), prostate, } \\
\text { lymphoma, adrenal-gland, liver, pituitary } \\
\text { gland, kidney }\end{array}$ \\
\hline Wood dust (1) - 11 & $\begin{array}{l}\text { nasopharynx, nasal } \\
\text { cavity and paranasal } \\
\text { sinus }\end{array}$ & & skin, mammary gland \\
\hline Toluene diisocyanate (2B) - 40 & & pancreas, lung & $\begin{array}{l}\text { stomach, liver, mammary gland, pancreas, } \\
\text { subcutaneous tissue, blood vessels }\end{array}$ \\
\hline Benzo $[a]$ pyrene $(1)-15$ & $\begin{array}{l}\text { lung, bladder, lip, oral } \\
\text { cavity, pharynx, arynx, } \\
\text { oesophagus, skin }\end{array}$ & & $\begin{array}{l}\text { lung, forestomach, esophageal, intestinal, } \\
\text { mammary gland, skin, upper respiratory } \\
\text { system, liver, tongue and larynx, anus, cervix }\end{array}$ \\
\hline Arsenic (III) oxide (1) - 2 & $\begin{array}{l}\text { lung, skin, urinary } \\
\text { bladder }\end{array}$ & $\begin{array}{l}\text { liver and bile duct, } \\
\text { prostate, kidney }\end{array}$ & stomach, lung \\
\hline 1,2-Dichloroethane (2B) - 2 & & $\begin{array}{l}\text { brain, stomach, } \\
\text { pancreas lymphatic, } \\
\text { hematopoietic cancers }\end{array}$ & $\begin{array}{l}\text { forestomach, lung, mammary gland, uterus/ } \\
\text { cervix, liver, blood vessels }\end{array}$ \\
\hline Hexachlorobenzene (2B) - 2 & & breast cancer & $\begin{array}{l}\text { liver, blood vessels, thyroid gland, kidney, } \\
\text { parathyroid gland, adrenal-gland }\end{array}$ \\
\hline
\end{tabular}

IARC - International Agency for Research on Cancer.

transportation and storage (11.2\%). The majority of night shift workers in the case of industry are men (70\%), while in the case of health care - women (80\%) [16].

Our study covered enterprises in municipal region of Łódź, which is the third largest industrial city in Poland, with a wide representation of operating enterprises, including producers of rubber products, plastics, furniture, electrical equipment, paper, and also textile materials. No official statistics reports for Łódź concerning the exact number of workers employed at nights, that we could use as an external reference for the assessment of the representativeness of our study for the city are available. However, we used data from SANEPID - a governmental institution that under the law controls all enterprises in the region. In fact, according to the regulations each new enterprise must be reported to the local SANEPID within 30 days from its establishing, therefore SANEPID documentation should cover all active entrepreneurs.

The aim of this work was to characterize the night shift work systems and other types of exposure reported in 44 enterprises in the area of Łódź. Our study shows that males, in comparison with females, work more frequently on night shifts (approximately 2/3 vs. 1/3 of the total population) and that the proportion of the night shift workers varies among enterprises, depending on their basic economic activity, and ranges from $11 \%$ in the plants dealing 
with manufacture of wearing apparel (PKD-14) up to 90\% in plants dealing with manufacture of furniture (PKD-31). In the investigated enterprises, a 3 -shift system, with 5 consecutive shifts, which is typical for the industrial settings, was the most frequent [3]. The counter-clockwise direction was more prevalent than the clockwise one. Different shift work systems may have different impact on health, and thus, several recommendations regarding organization of the shifts respecting ergonomic issues have been specified [3]. Fast rotating shifts systems and clockwise rotation are presumably better than slow rotating ones and counter-clockwise rotation [3]. Current recommendations of the International Labor Office indicate the need for at least two days of rest after each period of severely disturbed circadian rhythm, which is the case of working on several consecutive night shifts [17]. In the majority of the manufactures in our dataset, 5 days of shifts were followed by 2 days of rest, which is in line with these recommendations.

Our analysis showed that in none of the studied enterprises night shift work was a single exposure. We identified as many as 153 hazards, potential co-exposures of the night shift work with noise being the most common one (in 41 out of 44 plants). As many as 20 were classified by IARC as carcinogenic to humans or as probably (possibly) carcinogenic to humans. 10 of them have been classified as substances which are known or presumed to be carcinogenic to humans according to the European Union legislation. Occurrence of any agent classified by IARC to category $1,2 \mathrm{~A}$, or $2 \mathrm{~B}$ was reported by 23 enterprises $(66 \%)-$ with more restrictive CLP classification - by 15 enterprises $(34 \%)$. These numbers reflect potential for exposure rather than the number of exposed workers. In fact the number of the exposed is relatively small. Altogether only 132 employees (92 men - 70\% and 40 women - 30\%) were reported to be exposed to carcinogens - in the Central Register database. The gender representation varied by the enterprise, with only men exposed in electricity, gas, steam and air conditioning supply, but almost only women exposed to carcinogens in sewerage.

Our analyses were based on the data from two sources: 1) the questionnaire based survey of the enterprises via the support from the District SANEPID, and 2) data from the Central Register that operates at the Nofer Institute of Occupational Medicine in Łódź, Poland, and we observed some discrepancies between these two. These could be explained by differences for calendar periods for which data were collected, differences in classifications applied as well as some incompleteness.

The questionnaire-based survey sought the data on the current exposure for the year 2011, while the data from the Registry covered the period over the years 2005-2010. Of the agents reported to the register in 2010 only two, namely chromium(VI) compounds and heavy fuel oils were found in the survey from 2011. These too were reported to the Register continuously throughout the period 2005-2010.

The Register operates basing on the Polish legislation (Regulations of the Ministry of Health) [18-20]. According to it, an employer must register all carcinogenic or mutagenic agents present within the occupational environment of the plant. The data are reported to the Central Register at the Nofer Institute of Occupational Medicine in Łódź (Poland), through the Voivodeship Sanitary Inspector on a yearly basis. The regulation [19] specifies the list of carcinogens, which is based on the European Union legislation $[13,15]$.

Of 20 agents reported by the enterprises in the questionnaires, and classified to IARC group 1 or $2 \mathrm{~A}, 2 \mathrm{~B}$ - only 10 are present on the list of carcinogenic or mutagenic substances, preparations, agents or technological processes annexed to the Regulation of the Minister of Health of December 1, 2004 on the substances, preparations, agents or technological processes with carcinogenic or mutagenic effect in the workplace [19], which was obligatory for enterprises. Moreover, in some cases only very specific 
entities require reporting. For example, out of the compounds of cadmium, the list [19] includes only oxide, fluoride, chloride and sulfate(VI), and of the compounds of nickel, only its oxides and sulfides are listed. The employers when filling in the survey reported compounds of cadmium and nickel in general, without specifying which compounds in particular.

The same applies to petrol and mineral oils - the list includes complex substances derived from crude oil with given identification numbers (e.g. CAS number) - the employers in the case of the use of gasoline or mineral oil often find it difficult to identify a specific product. That is why in some cases, exposure to this type of complex chemical substances was not reported to the Central Register. In the case of hardwood dusts, the list of 2004 limits them to oak and beech dusts. The CLP list does not include diesel fumes - in this case, it is recommended to report them to the Central Register as benzo $[a]$ pyrene is a primary carcinogen found in these fumes. It should be noted that since 2012, the list of agents with carcinogenic or mutagenic effect in its previous form has no longer been valid [20], and employers are required to keep records of all substances that meet CLP classification criteria to hazard classes: "carcinogenicity" or "germ cell mutagenicity" category $1 \mathrm{~A}$ or 1B. In addition, registration of works performed in exposure to all types of hardwood dusts with carcinogenic effect without limiting them to oak and beech dusts is also obligatory.

We also identified some incompleteness of the Register. In the case of 8 companies, which have indicated a carcinogen in their questionnaires, the required information was not sent to the state regional sanitary inspector in accordance with the manner specified in the Regulation [19], and therefore this information is not included in the database of the Central Register. This points to the need for closer supervision of sanitary-epidemiological stations of their subordinate workplaces with respect to keeping records of works the performance of which requires contact with carcinogenic or mutagenic agents.

Our study was restricted to the manufactures that employed more than 100 workers, covering 59\% of all the identified plants (44 out of 75) (about $81 \%$ of all employees). Thus, the results of our analysis are limited to these larger manufactures in the region. None of the smaller manufactures had economic activity (PKD) that was not covered by the present analysis. Moreover, none of those plants reported occurrence of any carcinogenic agents and therefore none is presented in the Central Register.

Night shift work has been linked to breast, colon and prostate cancers [5,21]. Out of the 20 carcinogens found in our study, none has been identified by IARC as a strong risk factor for any of these cancer sites. In one epidemiological study, an association between breast cancer and hexachlorobenzene has been reported [22]. However, the results of majority of the epidemiological studies do not support this finding [23]. Some studies have linked cadmium and cadmium compounds or arsenic compounds with prostate cancer [24-27]. Six other agents, i.e. styrene, benzene, wood dust, toluene diisocyanate, benzo $[a]$ pyrene, and 1,2-dichloroethane in experimental studies on animals have been shown to induce mammary glands tumors (Table 6) [28-32].

Even if the number of workers potentially exposed to these agents was relatively small, our study indicates that further epidemiological studies on the health effects of night shift work in industrial settings should include thorough exposure assessment in order to elucidate potential confounders.

In conclusion, we observed that in none of the workplaces the night shift work was a single exposure, but co-exposure to carcinogenic agents is relatively rare. The identified limits of both, the survey and the Register data that we explored indicate that in order to verify and improve completeness of the data there is a need to use all available sources of information regarding exposure. 


\section{ACKNOWLEDGEMENTS}

We thank MSc Urszula Jędrzejczyk - District Sanitary Inspector and staff of District Sanitary-Epidemiological Station (SANEPID) in Łódź for their contribution to organization of the study and data collection.

\section{REFERENCES}

1. Stevens RG. Electric power use and breast cancer: A hypothesis. Am J Epidemiol. 1987;125(4):556-61.

2. Straif K, Baan R, Grosse Y, Secretan B, El Ghissassi F, Bouvard V, et al. Carcinogenicity of shift-work, painting, and fire-fighting. Lancet Oncol. 2007;8(12):1065-6, http://dx.doi. org/10.1016/S1470-2045(07)70373-X.

3. International Agency for Research on Cancer. Firefighting and Shiftwork. Monographs on the Evaluation of Carcinogenic Risk to Humans. Painting. Vol. 98. Lyon: IARC; 2010.

4. Lie JA, Kjuus H, Zienolddiny S, Haugen A, Stevens RG, Kjaerheim K. Night work and breast cancer risk among Norwegian nurses: assessment by different exposure metrics. Am J Epidemiol. 2011;173(11):1272-9, http://dx.doi. org/10.1093/aje/kwr014.

5. Hansen J, Stevens RG. Case-control study of shift-work and breast cancer risk in Danish nurses: impact of shift systems. Eur J Cancer. 2012;48(11):1722-9, http://dx.doi.org/10.1016/ j.ejca.2011.07.005.

6. Poole EM, Schernhammer ES, Tworoger SS. Rotating night shift work and risk of ovarian cancer. Cancer Epidemiol Biomarkers Prev. 2011;20(5):934-8, http:/dx.doi. org/10.1158/1055-9965.EPI-11-0138.

7. Pesch B, Harth V, Rabstein S, Baisch C, Schiffermann M, Pallapies D, et al. Night work and breast cancer - results from the German GENICA study. Scand J Work Environ Health. 2010;36(2):134-41, http://dx.doi.org/10.5271/ sjweh.2890.

8. Villeneuve S, Fevotte J, Anger A, Truong T, Lamkarkach F, Gaye $\mathrm{O}$, et al. Breast cancer risk by occupation and industry: analysis of the CECILE study, a population-based case-control study in France. Am J Ind ed. 2011;54(7):499-509.

9. Kubo T, Oyama I, Nakamura T, Kunimoto M, Kadowaki K, Otomo H, et al. Industry-based retrospective cohort study of the risk of prostate cancer among rotating-shift workers. Int J Urol. 2011;18(3):206-11, http://dx.doi.org/10.1111/ j.1442-2042.2010.02714.x.

10. Pronk A, Ji BT, Shu XO, Xue S, Yang G, Li HL, et al. Night-shift work and breast cancer risk in a cohort of Chinese women. Am J Epidemiol. 2010;171(9):953-9, http:// dx.doi.org/10.1093/aje/kwq029.

11. Pukkala E, Martinsen JI, Lynge E, Gunnarsdottir HK, Sparen P, Tryggvadottir L, et al. Occupation and cancer - follow-up of 15 million people in five Nordic countries. Acta Oncol. 2009;48(5):646-790, http://dx.doi. org/10.1080/02841860902913546.

12. Regulation (EC) No 1893/2006 of the European Parliament and of the Council of 20 December 2006 estabilishing the statistical classification of economic activities NACE Revision 2 and amending Council Regulation (EEC) No 3037/90. OJ L 393 (Dec 30,2006, p. 1-39).

13. Regulation (EC) No 1272/2008 of the European Parliament and of the Council of 16 December 2008 on classification, labelling and packaging of substances and mixtures, amending and repealing Directives 67/548/EEC and 1999/45/EC, and amending Regulation (EC) No 1907/2006. OJ L 353 (Dec 31, 2008. p. 1-1355) with ATP.

14. International Agency for Research on Cancer. Monographs on the Evaluation of Carcinogenic Risk to Humans. Preamble. Lyon: IARC; 2006.

15. Directive 2004/37/EC of the European Parliament and of the Council of 29 April 2004 on the protection of workers from the risks related to exposure to carcinogens or mutagens at work. Sixth individual Directive within the meaning of Article 16(1) of Council Directive 89/391/EEC. OJ L 158 (Apr 30, 2004, p. 50-76); OJ L 229 (Jun 29, 2004, p. 23-34). 16. Zgierska A. Employment in national economy in 2011. Warszawa: Central Statistical Office; 2012. 
17. Tucker P, Folkard S. Conditions of work and employment. working time, health and safety: A research synthesis paper. Series No. 31. Geneva: International Labour Office; 2012.

18. [Regulation of the Minister of Health and Social Care of 11 September 1996 on carcinogens in the workplace and health surveillance of workers exposed to these factors]. Journal of Laws of 1996, no 121, item 571. Polish.

19. [Regulation of the Minister of Health of 1 December 2004 on substances, preparations, agents or technological processes with carcinogenic or mutagenic effect in the workplace (Journal of Laws No 280/2004, item 2771 as amended)]. Journal of Laws of 2004, no 160, item 1356. Polish.

20. [Regulation of the Minister of Health of 24 July 2012 on chemical substances and their mixtures, agents or technological processes with carcinogenic or mutagenic effect in the work environment]. Journal of Laws of 2012, no 0, item 890. Polish.

21. Brudnowska J, Pepłońska B. [Night shift work and cancer risk: A literature review]. Med Pr. 2011;62(3):323-38. Polish.

22. Charlier C, Foidart JM, Pitance F, Herman P, Gaspard U, Meurisse M, et al. Environmental dichlorodiphenyltrichlorethane or hexachlorobenzene exposure and breast cancer: Is there a risk? Clin Chem Lab Med. 2004;42(2):222-7, http:// dx.doi.org/10.1515/CCLM.2004.040.

23. International Agency for Research on Cancer. Monographs on the evaluation of carcinogenic risk to humans. Some thyrotropic agents. Vol. 79. Lyon: IARC; 2001.

24. Vinceti M, Venturelli M, Sighinolfi C, Trerotoli P, Bonvicini F, Ferrari A, et al. Case-control study of toenail cadmium and prostate cancer risk in Italy. Sci Total
Environ. 2007;373(1):77-81, http://dx.doi.org/10.1016/j.scitotenv.2006.11.005.

25. Sahmoun AE, Case LD, Jackson SA, Schwartz GG. Cadmium and prostate cancer: A critical epidemiologic analysis. Cancer Invest. 2005;23(3):256-63, http://dx.doi.org/10.1081/ CNV-200055968.

26. Chen CJ, Wang CJ. Ecological correlation between arsenic level in well water and age-adjusted mortality from malignant neoplasms. Cancer Res. 1990;50(17):5470-4.

27. Wu MM, Kuo TL, Hwang YH, Chen CJ. Dose-response relation between arsenic concentration in well water and mortality from cancers and vascular diseases. Am J Epidemiol. 1989;130(6):1123-32.

28. International Agency for Research on Cancer. Monographs on the Evaluation of Carcinogenic Risk to Humans. Re-evaluation of some organic chemicals, hydrazine and hydrogen peroxide. Vol. 71. Lyon: IARC; 1999.

29. International Agency for Research on Cancer. Monographs on the Evaluation of Carcinogenic Risk to Humans. Some traditional herbal medicines, some mycotoxins, naphthalene and styrene. Vol. 82. Lyon: IARC; 2002.

30. International Agency for Research on Cancer. Monographs on the Evaluation of Carcinogenic Risk to Humans. A Review of Human Carcinogens: Arsenic, Metals, Fibres and Dusts. Vol. 100C. Lyon: IARC; 2012.

31. International Agency for Research on Cancer. Monographs on the Evaluation of Carcinogenic Risk to Humans. A Review of Human Carcinogens: Chemical Agents and Related Occupations, Vol. 100F. Lyon: IARC; 2012.

32. National Toxicology Program. Report on Carcinogens. 12th ed. Bethesda, MD (USA): National Institutes of Health; 2011.

This work is available in Open Access model and licensed under a Creative Commons Attribution-NonCommercial 3.0 Poland License - http://creativecommons.org/ licenses/by-nc/3.0/pl/deed.en. 